\title{
GŁOSOWANIE KORESPONDENCYJNE ORAZ GŁOSOWANIE PRZEZ PEŁNOMOCNIKA JAKO ALTERNATYWNE METODY GKOSOWANIA W ŚWIETLE POLSKIEGO KODEKSU WYBORCZEGO
}

\section{Prawo wyborcze a frekwencja wyborcza}

Prawo wyborcze współczesnych państw demokratycznych jest sferą prawa publicznego, która podlega permanentnym i najczęściej ewolucyjnym modyfikacjom, które są podyktowane m.in. zmianami koncepcji ustrojowych państwa, czasem doraźnymi potrzebami partii politycznych, ale czasem także wynikają z potrzeb doskonalenia samego prawa wyborczego, tak by realizowało ono jak najlepiej funkcje wynikające z zasady demokracji przedstawicielskiej.

Jedną ze współczesnych tendencji obserwowanych $\mathrm{w}$ zakresie zmian w prawie wyborczym są próby zaradzenia coraz bardziej doskwierającemu europejskim demokracjom problemowi niskiej frekwencji wyborczej. ${ }^{1}$ Ważnym polem badawczym stała się jednocześnie analiza przyczyn tego zjawiska, a także metod mu zapobiegania, także w zakresie tzw. inżynierii wyborczej. Zmiany w zakresie prawa wyborczego stają się tym samym reakcją na dwie kategorie przyczyn niskiej frekwencji. Po pierwsze, są to sytuacje skutkujące absencją zawinioną, czyli przypadki, w których wyborca ma możliwość uczestniczenia w procesie wyborczym, ale z niej w sposób świadomy nie korzysta. Wynika to m.in. ze zniechęcenia oraz braku zaufania wyborców do polityki i polityków, braku alternatywy wyborczej lub w ogóle potrzeby angażowania się w życie publiczne. Po drugie, są to przyczyny skutkujące tzw. absencją przymusową, a więc takie sytuacje, w których wyborca pomimo chęci oddania głosu, nie może tego zrobić - nie ma bowiem fizycznych możliwości oddania głosu z powodów takich jak np. choroba, podeszły wiek, niepełnosprawność,

J. Blondel, R. Sinnott, P. Svensson, Representation and voter participation, „European Journal of Political Research" 1997, nr 32, s. 243-244. R.L. Pintor, M. Gratschew (red.), Voter Turnout Since 1945: A global Report, Stokholm 2002 oraz A. Ellis, M. Gratschew, J.H. Pmmet, E. Thiessen, Aktywizowanie wyborców. Inicjatywy z różnych państw świata, Warszawa 2008, s. 13-15. 
odległość od miejsca głosowania. Jak podaje J.Zbieranek, tego rodzaju bariery dotyczą w Polsce około 30\% wyborców, ${ }^{2}$ co pokazuje, jak istotne jest ich niwelowanie w kontekście skutecznej realizacji zasady powszechności wyborów. Mechanizmami prawa wyborczego o takich właśnie celach są alternatywne metody głosowania. Celem badawczym niniejszego opracowania jest przegląd polskich rozwiązań normatywnych w tym zakresie i odpowiedź na pytanie, w jaki sposób ustawodawca stara sie reagować na zjawisko kryzysu partycypacji.

\section{Metody głosowania alternatywnego w Kodeksie wyborczym - uwagi wprowadzające}

W dniu 5 stycznia 2011 roku uchwalono w Polsce ustawę - Kodeks wyborczy, który zaczął obowiązywać z dniem 1 sierpnia 2011 roku. ${ }^{3}$ Koncepcja jednego aktu normatywnego, zastępującego regulacje wyborcze, które dotychczas obowiązywały w Polsce w zakresie wyborów parlamentarnych, prezydenckich, samorządowych oraz tzw. europejskich miała oczywiście ujednolicić polskie prawo wyborcze, ${ }^{4}$ jednak przy tej okazji, przeprowadzono ostrożne reformy prawa wyborczego, także w zakresie nowych możliwości partycypacji obywateli w życiu publicznym w postaci alternatywnych metod głosowania. W państwie demokratycznym można wręcz mówić o ,zobowiązaniu ustawodawcy do stworzenia realnej możliwości uczestniczenia w wyborach każdemu, komu przysługuje czynne prawo wyborcze", 5 co $\mathrm{w}$ świetle ewoluujących w tym kierunku standardów obserwowanych w innych państwach demokratycznych spowodowało, że stworzenie takich prawnych ram umożliwiających alternatywne oddanie głosu było wręcz nieuchronne.

Polski Kodeks wyborczy przewiduje dwie metody głosowania alternatywnego: głosowanie korespondencyjne oraz głosowanie przez pełnomocnika. Znajdują zastosowanie niemal we wszystkich procedurach wyborczych (z wyłączeniami, o których będzie mowa w dalszej części tekstu).

Oba rozwiązania związane są z odstępstwami od zasady osobistego oddania głosu, w sytuacjach w których rygorystyczne wymaganie oddania głosu osobiście w lokalu wyborczym powodowałoby albo faktyczną niemożliwość głosowania lub znaczące utrudnienie, praktycznie zniechęcające wyborcę do udziału w wyborach. Jak pisze G. Kryszeń, wymóg osobistego głosowania w lokalu wyborczym nie jest

J. Zbieranek, Nowe procedury: głosowanie korespondencyjne i przez pełnomocnika, (w:) K. Skotnicki (red.), Kodeks wyborczy. Wstępna ocena, Warszawa 2011, s. 37-40. Patrz także A. Błaszczak, J. Zbieranek, Gwarancje korzystania z czynnego prawa wyborczego przez osoby starsze i osoby z niepełnosprawnościami, „Biuletyn RPO. Źródła" 2012, nr 8, s. 9-10, gdzie autorzy podają dane demograficzne pokazujące skalę znaczenia różnych barier fizycznych utrudniających lub wręcz uniemożliwiających głosowanie.

3 Dz.U. z 2011 r. Nr 21, poz. 112 z późn. zm.

$4 \quad \mathrm{Na}$ temat idei unifikacji prawa wyborczego oraz o pracach legislacyjnych nad Kodeksem wyborczym patrz K. Skotnicki, Przebieg prac nad Kodeksem wyborczym, (w:) K. Skotnicki (red.), Kodeks wyborczy. Wstępna ocena, Warszawa 2011, s. 11-35. M. Chmaj, W. Skrzydło, System wyborczy w Rzeczypospolitej Polskiej, Warszawa 2011, s. 39. 
bezwzględnie przestrzegany w dużej liczbie państw, a wyjątki wobec niego czynione są głównie z myślą o zwiększeniu frekwencji głosujących, a tym samym o umocnieniu zasady powszechności wyborów. ${ }^{6}$ Należy przy tym poczynić uwagę, iż wszelkie alternatywne metody głosowania są rozumiane jako alternatywne wobec tradycyjnego osobistego głosowania w lokalu wyborczym. Należy przy tym dostrzec różnicę pomiędzy kwestią osobistego głosowania w lokalu wyborczym a kwestią osobistego głosowania rozumianego jako samodzielne i suwerenne dokonanie czynności związanych z oddaniem głosu. Takie rozumienie osobistego głosowania przyjmuje Kodeks wyborczy, uznając w w art. 38 §, że głosowanie korespondencyjne jest głosowaniem osobistym. W przypadku głosowania przez pełnomocnika analogicznej regulacji ustawa nie przewiduje.

\section{Głosowanie korespondencyjne według Kodeksu wyborczego}

Wspomniane głosowanie korespondencyjne jest rozwiązaniem, które Kodeks wyborczy wprowadził po raz pierwszy do polskiego prawa wyborczego. ${ }^{7}$ Jest to metoda głosowania, która budzi kontrowersje, ale jest dopuszczalna w państwach członkowskich Rady Europy. ${ }^{8}$ Jest ona przewidziana w prawie wyborczym: Australii, Bangladeszu, Bośni, Estonii, Finlandii, Grecji, Hiszpanii, Holandii, Indii, Irlandii, Islandii, Japonii, Kanady, Korei Południowej, Kanady, Lesotho, Niemiec, Nowej Zelandii, Pakistanu, Portugalii, RFN, Słowenii, Stanów Zjednoczonych, Szwajcarii, Szwecji, Wielkiej Brytanii, Litwy, Łotwy i Filipin. W zdecydowanej większości tych państw, głosowanie korespondencyjne zostało zawężone do kręgu osób pozostających poza granicami państwa, a tylko w nielicznych uprawnienie to nadano również obywatelom znajdującym się na ich terytoriach, przy czym w części z nich objęto nim wszystkich wyborców, a w części tylko niektóre ich kategorie, np. osoby niepełnosprawne lub w podeszłym wieku. ${ }^{9}$

$6 \quad$ G.Kryszeń, Standardy prawne wolnych wyborów parlamentarnych, Białystok 2007, s. 222.

7 Pierwsza próba wprowadzenia w Polsce mechanizmu głosowania korespondencyjnego miała miejsce podczas prac nad ordynacją wyborczą do Parlamentu Europejskiego na przełomie 2002 i 2003 roku, patrz J. Zbieranek, Nowe procedury..., op. cit., s. 48-49, 51-56.

8 Komisja Wenecka - w Kodeksie dobrej praktyki wyborczej uwzględnia tę metodę głosowania czyniąc jednak zastrzeżenia podmiotowe, a także związane niezawodnością systemu pocztowego - Code of good practises in electoral matters. Guidelines and explanatory reports, Adopted by the Venice Commission at its 52nd session (Wenecja, 18-19 październik 2002), Opinion no. 190/2002, CDL-AD (2002) 23 rev, s. 21, Komisja Wenecka głosowaniom na odległość poświęca także Report on the Compatibility of Remote Voting and Electronic Voting with the Standards of The Council of Europe. Adopted by the Venice Commission at its 58th Plenary Session (Wenecja, 12-13 marzec 2004) on the basis of a contribution by Mr Christoph Grabenwarter (substitute member, Austria), Study no. 260 / 2003, CDL-AD(2004)012. Oba dokumenty dostępne na www.venice.coe.int (data dostępu: 12.06.2014 r.)

9 Wyliczenie państw, w których prawie wyborczym występuje głosowanie korespondencyjne sporządzono na podstawie: Z.Szabo, Distance voting, Raport sporządzonego na potrzeby Zgromadzenia Parlamentarnego Rady Europy, Doc. nr 11434 z 12 lipca 2007, Parliamentary Assembly Working Papers, Ordinary Session 21-25 January 2008, Tom 1, s. 90; G. Kryszeń, Standardy prawne..., op. cit., s. 224-225; M. Qvortrup, Absentee Voting in a Comparative Perspective: A Preliminary Assessment of the Experiences with Postal Voting, Submission for 
Nowelizacja Kodeksu wyborczego z dnia 11 lipca 2014 r. ${ }^{10}$ rozszerzyła możliwość głosowania korespondencyjnego, przyznając taką opcję każdemu wyborcy. Przed tą nowelizacją polski Kodeks wyborczy przewidywał, iż ta metoda głosowania będzie dostępna jedynie dla wyborców niepełnosprawnych oraz dla wyborców głosujących w obwodach głosowania utworzonych za granicą. Aktualnie Kodeks wyborczy poświęca głosowaniu przepisy zawarte w Dziale I, rozdziale 6a (poprzednio były to przepisy zawarte Dziale I, rozdziałach 7a i 8). Ograniczeniem zakresu głosowania korespondencyjnego jest wyłączenie tej metody w wyborach samorządowych, przy czym wyborcy niepełnosprawni ${ }^{11}$ mogą głosować korespondencyjnie także i w tych wyborach. Głosowanie korespondencyjne jest ponadto wyłączone w przypadku głosowania w obwodach głosowania utworzonych w zakładzie opieki zdrowotnej, domu pomocy społecznej, zakładzie karnym i areszcie śledczym, domu studenckim oraz w obwodach głosowania utworzonych na polskich statkach morskich, a także w przypadku udzielenia przez wyborcę niepełnosprawnego pełnomocnictwa do głosowania.

Zamiar głosowania korespondencyjnego w kraju wyborca zgłasza wójtowi (burmistrzowi lub prezydentowi miasta), a za granicą właściwemu terytorialnie konsulowi do 15 dnia przed dniem wyborów. Po kontroli formalnej wniosku wyborcę wpisuje się do właściwego spisu wyborców na terenie gminy, w której wyborca jest wpisany do rejestru wyborców. W przypadku głosowania korespondencyjnego poza granicami kraju, wyborcę umieszcza się w spisie wyborców w obwodzie głosowania właściwym dla obwodowej komisji wyborczej, wskazanej rozporządzeniem ministra ds. zagranicznych, w którym to wskazuje się co najmniej jedną obwodową komisję wyborczą na obszarze właściwości terytorialnej każdego konsula właściwą dla celów głosowania korespondencyjnego.

Wyborca, który zgłosił zamiar głosowania korespondencyjnego w kraju, otrzymuje z urzędu gminy, nie później niż 7 dni przed dniem wyborów, pakiet wyborczy. W przypadku wyborcy, który wyraził zamiar głosowania korespondencyjnego za granicą, za wysłanie pakietu wyborczego odpowiedzialny jest właściwy konsul, który powinien to zrobić niezwłocznie po otrzymaniu od właściwej komisji wyborczej kart do głosowania, jednak nie później niż 10 dni przed dniem wyborów.

$\mathrm{W}$ skład pakietu wyborczego, zgodnie z art. $53 \mathrm{~g} \S 1$. Kodeksu wyborczego wchodzą:

1) koperta zwrotna;

The Joint Standing Committee on Electoral Matters, Australian Federal Parliament, tekst dostępny w bazie Academia,edu (data dostępu: 12.06.2014 r.). J.Zbieranek, Nowe procedury..., op. cit., s. 46-48; J. Zbieranek., Alternatywne procedury głosowania w Polsce na tle państw Unii Europejskiej, „Biuro Analiz Sejmowych” 2011, nr 3, s. 99-102.

10 Ustawa z dnia 11 lipca 2014 r. o zmianie ustawy - Kodeks wyborczy oraz niektórych innych ustaw (Dz.U. z 2014 r. poz. 1072)

11 O znacznym lub umiarkowanym stopniu niepełnosprawności w rozumieniu ustawy z dnia 27 sierpnia $1997 \mathrm{r}$. o rehabilitacji zawodowej i społecznej oraz zatrudnianiu osób niepełnosprawnych (Dz.U. z 2011 r. Nr 127, poz. 721, z późn. zm.). 
2) karta lub karty do głosowania;

3) koperta na kartę lub karty do głosowania,

4) instrukcja głosowania korespondencyjnego;

5) nakładka lub nakładki na kartę lub karty do głosowania sporządzone w alfabecie Braille'a - jeżeli wyborca zażądał ich przesłania;

6) oświadczenie o osobistym i tajnym oddaniu głosu na karcie do głosowania.

Wyborca głosujący korespondencyjnie po wypełnieniu karty do głosowania wkłada ją do koperty na kartę do głosowania, którą zakleja, a następnie kopertę tę wkłada do koperty zwrotnej łącznie z podpisanym oświadczeniem i przesyła ją w przypadku głosowania w kraju - do właściwej obwodowej komisji wyborczej, ${ }^{12}$ a w przypadku głosowania za granicą na własny koszt na adres właściwego konsula. ${ }^{13}$ Koperty na kartę do głosowania wyjęte z kopert zwrotnych dostarczonych do obwodowej komisji wyborczej wrzucane są do urny wyborczej. W przypadku głosowania korespondencyjnego za granicą, konsul przekazuje właściwej obwodowej komisji wyborczej koperty zwrotne, które otrzymał do czasu zakończenia głosowania, co powoduje, że karty do głosowania trafią do właściwej urny nieco później.

Polskie rozwiązania w zakresie głosowania korespondencyjnego należy uznać za nowoczesne. Ustawodawca poszerzył krąg osób, które mogą głosować w ten sposób, umożliwiając skorzystanie z tej metody głosowania wszystkim wyborcom. Dopiero praktyka kilku najbliższych wyborów pokaże, czy mechanizm cieszy się popularnością ${ }^{14}$ oraz czy nie stał się przedmiotem nadużyć, bowiem ta metoda głosowania niesie ze sobą również zagrożenia. Mogą one być związane m.in. z niebezpieczeństwem niedochowania tajności głosowania - w tym stwarzając warunki dla potencjalnego zjawiska ,sprzedawania głosów”, czy po prostu wywierania wpływu na głosujących (np. w ramach danego gospodarstwa domowego), a także z niebezpieczeństwem fałszerstw, niedoskonałości systemu pocztowego czy problemów w zakresie sprostania wymaganiom formalnym takiego oddawania głosów. ${ }^{15}$ Pomimo tych wątpliwości Komisja Wenecka - we wspominanym powyżej kodeksie

12 Wyborca może przekazać kopertę zwrotną przedstawicielowi operatora wyznaczonego w rozumieniu ustawy z dnia 23 listopada 2012 r. - Prawo pocztowe (Dz.U. z 2012 r., poz. 1529). Możliwe jest także oddanie głosu przed dniem głosowania, jako że wyborca może osobiście dostarczyć kopertę zwrotną w przypadku głosowania w kraju - do właściwego urzędu gminy, a w przypadku głosowania za granicą - do właściwego konsula. Koperty zwrotne w przypadku głosowania w kraju są zwolnione z opłat pocztowych.

14 W wyborach parlamentarnych w 2011 roku z głosowania korespondencyjnego w kraju skorzystało 807 osób, przy czym tylko część z nich zrobiła to skutecznie (647 osób) - patrz: A. Błaszczak, J. Zbieranek, Gwarancje korzystania..., op. cit., s. $69-70$.

15 O korzyściach i zagrożeniach głosowania korespondencyjnego pisze D.P. Bannon, Electoral participation and Non Voter Segmentation, (w:) W.W. Wymer Jr, J. Lees - Marshment (red.), Current Issues in Political Marketing, Binghampton 2006, s. 114-116, patrz także M.Qvortrup, First past the Postman: voting by Mail In Comparative Perspective, „The Political Quarterly” 2005, Vol. 76, No. 3, s. 416-418, gdzie odnajdujemy ponadto uwagi na temat genezy głosowania korespondencyjnego oraz efekty wprowadzenia tego rodzaju głosowania m.in. w Wielkiej Brytanii, Australii, Nowej Zelandii. 
dobrej praktyki wyborczej uwzględnia tę metodę głosowania czyniąc jednak zastrzeżenia podmiotowe, a także związane z niezawodnością systemu pocztowego.

Polski ustawodawca za szczególnie niebezpieczny dla głosowania korespondencyjnego uznaje czyn polegający na nieuprawnionym otwarciu lub zniszczeniu pakietu wyborczego lub zaklejonej koperty, poświęcając mu przepis karny (art. 513a), w którym jest mowa o karze grzywny za takie zachowania.

Podobnie jak w przypadku głosowana przez pełnomocnika, w sprawie głosowania korespondencyjnego, w cytowanym już wyroku, wypowiedział się Trybunał Konstytucyjny, stwierdzając, iż głosowanie korespondencyjne nie narusza zasady tajności głosowania oraz standardów rzetelności państwa demokratycznego, oceniając tę metodę głosowania pozytywnie jako alternatywną formę głosowania realizującą zasadę powszechności wyborów. ${ }^{16}$

\section{Głosowanie przez pełnomocnika według Kodeksu wyborczego}

Stosunkowo nowym rozwiązaniem w polskim prawie wyborczym jest druga przewidziana przez Kodeks wyborczy alternatywna metoda głosowania - głosowanie przez pełnomocnika. ${ }^{17}$ Jak podaje G. Kryszeń, taka metoda głosowania ma miejsce w prawie wyborczym takich państw, jak: Belgia, Francja, Ghana, Gruzja, Gujana, Hiszpania, Holandia, Łotwa, Mali, Szwecja i Wielka Brytania, przy czym ujęcie tego mechanizmu w poszczególnych państwach różni się kręgiem osób uprawnionych do udzielania pełnomocnictwa oraz jego przyjmowania, liczbą pełnomocnictw możliwych do przyjęcia przez jednego wyborcę, niejednakowym okresem ważności pełnomocnictwa i sposobem jego udzielania. ${ }^{18}$

Polska ustawa poświęca głosowaniu przez pełnomocnika Dział I rozdział 7. ${ }^{19}$ Także w polskim wydaniu jest to rozwiązanie o ograniczonym podmiotowo charakterze - bowiem zgodnie z art. 54 może z takiego sposobu głosowania skorzystać tylko wyborca niepełnosprawny o znacznym lub umiarkowanym stopniu niepełno-

16 Wyrok TK z 20 lipca 2011 r., K 9/11.

17 Podczas gdy trwały prace nad Kodeksem wyborczym, głosowanie przez pełnomocnika zostało wprowadzone do obowiązujących w wyborach prezydenckich i samorządowych ordynacji wyborczych, na podstawie których odbyły się w 2010 r. wybory. Z procedury głosowania przez pełnomocnika skorzystało wtedy po kilkanaście tysięcy wyborców w podeszłym wieku lub z niepełnosprawnościami. Patrz A .Błaszczak, J. Zbieranek, Gwarancje korzystania..., op. cit., s. 22.

18 G. Kryszeń, Standardy prawne..., op. cit., s. 223, o różnicach pisze J. Zbieranek, Nowe procedury..., op. cit., s. 42-44, pisze J. Zbieranek, Alternatywne procedury..., op. cit., s. 96-98. Patrz także A. Krasnowolski, Głosowanie przez pełnomocnika, głosowanie antycypowane i głosowanie korespondencyjne w krajach europejskich i Kanadzie, Warszawa 2006, s. 10 i nast.; K. Skotnicki, Zasada powszechności w prawie wyborczym. Zagadnienia teorii i praktyki, Łódź 2000, s. 263 i nast.

19 Idea głosowania przez pełnomocnika podobnie zresztą jak i głosowania korespondencyjnego była jednym z kilku spornych obszarów podczas prac nadzwyczajnej komisji sejmowej zajmującej się projektem ustawy - patrz K. Skotnicki, Przebieg prac..., op. cit., s. 25. 
sprawności ${ }^{20}$ lub taki, który najpóźniej w dniu głosowania kończy 75 lat. Tylko taka osoba może udzielić pełnomocnictwa do głosowania. Ustawodawca zdecydował ponadto, iż taki sposób głosowania jest wyłączony w przypadku głosowania w odrębnych obwodach głosowania oraz w obwodach głosowania utworzonych za granicą i na polskich statkach morskich, a także w przypadku zgłoszenia przez wyborcę niepełnosprawnego zamiaru głosowania korespondencyjnego.

Przepisy Kodeksu wyborczego precyzują, kto może być pełnomocnikiem oraz jak wygląda procedura udzielania i wycofywania pełnomocnictwa. Zgodnie z art. 55 ustawy, pełnomocnikiem może być tylko osoba wpisana do rejestru wyborców w tej samej gminie co udzielający pełnomocnictwa do głosowania. Kodeks słusznie dopuszcza także sytuację, w której pełnomocnictwa udziela się osobie posiadającej zaświadczenie o prawie do głosowania (jeżeli przepisy szczególne dotyczące danych wyborów przewidują możliwość uzyskania takiego zaświadczenia), umożliwiając tym samym np. umocowanie członka rodziny zamieszkującego inną gminę. Kodeks umożliwia przyjęcie pełnomocnictwa tylko od jednego wyborcy - wyjątek jest przewidziany w przypadku wyliczonych kategorii osób - można dodatkowo być pełnomocnikiem dwóch osób, z których jedna jest członkiem rodziny, przysposobionym, w stosunku opieki lub kurateli. ${ }^{21}$ Ma to uniemożliwić wykorzystywanie tego mechanizmu wbrew intencjom ustawodawcy, np. poprzez odpłatne zbieranie pełnomocnictw do głosowania. ${ }^{22}$

Ze względu na bezpieczeństwo wyborów, sama procedura głosowania przez pełnomocnika jest sformalizowana. Wyborca najpóźniej w dziewiątym dniu przed dniem wyborów zgłasza wniosek o sporządzenie aktu pełnomocnictwa do właściwego miejscowo wójta, dołączając stosowne dane o mocodawcy, w tym dokumenty identyfikujące go jako uprawnionego do głosowania w ten sposób, a także dokumenty poświadczające zdolność danej osoby do bycia pełnomocnikiem. Akt pełnomocnictwa sporządzany jest przed wójtem lub urzędnikiem przez niego upoważnionym w miejscu zamieszkania wyborcy lub innym wnioskowanym przez wyborcę na terenie gminy.

O ile sama instytucja głosowania przez pełnomocnika jest niewątpliwie korzystna z punktu widzenia zasady powszechności wyborów, to trzeba mieć na uwadze, iż budzi ona kontrowersje z punktu widzenia innych zasad wyborczych. Biorąc pod uwagę głosy doktryny, G. Kryszeń wskazuje, iż wątpliwości budzi jej zgodność

20 W rozumieniu ustawy z dnia 27 sierpnia 1997 r. o rehabilitacji zawodowej i społecznej oraz zatrudnianiu osób niepełnosprawnych (Dz.U. z 2011 r. Nr 127, poz. 721). Zakres osób, które mogą skorzystać z tej metody głosowania był przedmiotem kontrowersji podczas prac nad Kodeksem wyborczym, a także już i po jego wejściu w życie - patrz J. Zbieranek, Nowe procedury..., op. cit., s. 56.

21 Pełnomocnikiem nie może być osoba wchodząca w skład komisji obwodowej właściwej dla obwodu głosowania osoby udzielającej pełnomocnictwa do głosowania, a także mężowie zaufania, jak również kandydaci w danych wyborach.

22 Kodeks wyborczy w art. $60 \S 2$ zabrania literalnie pełnomocnikowi pobierania od udzielającego pełnomocnictwa do głosowania żadnych opłat za głosowanie w jego imieniu w wyborach, a w art. 60 § 3 zakazuje udzielania pełnomocnictwa do głosowania w zamian za jakąkolwiek korzyść majątkową lub osobistą. 
z zasadą bezpośredniości wyborów oraz z zasadą tajności głosowania, ${ }^{23}$ co prowadzi go do wniosku, że głosowanie przez pełnomocnika jest sprzeczne $\mathrm{z}$,elementarnymi wymogami wolnych wyborów." 24 Podstawowym zagrożeniem dla idei głosowania przez pełnomocnika jest bowiem sytuacja, w której pełnomocnik głosuje zgodnie $\mathrm{z}$ własnymi poglądami, a nie według woli wyborcy udzielającego pełnomocnictwa. ${ }^{25}$ $\mathrm{Na}$ temat wątpliwości powstających na tle głosowania przez pełnomocnika wypowiedział się Trybunał Konstytucyjny, oceniając pozytywnie tę instytucję - jako dodatkową gwarancję korzystania przez obywateli z czynnego prawa wyborczego. Trybunał odrzucił argumenty, iż głosowanie przez pełnomocnika jest sprzeczne z zasadą bezpośredniości głosowania, argumentując, iż zasada ta oznacza jednostopniowość aktu wyborczego i nie rodzi obowiązku głosowania osobistego. ${ }^{26}$

Biorąc pod uwagę poglądy doktryny wskazujące na niebezpieczeństwa związane z głosowaniem przez pełnomocnika, polski model normatywny tego mechanizmu wyborczego, ograniczony podmiotowo i stosunkowo sformalizowany, wydaje się być rozwiązaniem na tyle ostrożnym, iż traktowany jako wyjątek od zasady osobistego głosowania mieści się w kanonach państwa demokratycznego, aczkolwiek dopiero praktyka kilku następnych wyborów pokaże, czy mechanizm ten nie jest przedmiotem nadużyć.

Warto także zauważyć, iż Kodeks wyborczy przewiduje przepisy karne związane z instytucją głosowania przez pełnomocnika, mające dodatkowo zapobiegać patologicznym, nastawionym na uzyskanie korzyści, zachowaniom związanym z udzieleniem pełnomocnictwa - i to zarówno po stronie udzielającego pełnomocnictwa, jak i samego pełnomocnika. $Z$ jednej strony bowiem, zgodnie $\mathrm{z}$ artykułem 511, kto pobiera od udzielającego pełnomocnictwa do głosowania opłatę za głosowanie w jego imieniu - podlega karze grzywny, a zgodnie $\mathrm{z}$ art. 512, kto udziela pełnomocnictwa do głosowania w zamian za jakąkolwiek korzyść majątkową lub osobistą - podlega karze aresztu albo grzywny.

\section{Konkluzje}

Prezentowane powyżej rozwiązania polskiego Kodeksu wyborczego niewątpliwie służą realizacji zasady powszechności wyborów, która sama wyznacza krąg osób, które tworzą elektorat - jednak sprawą kluczową w kontekście zagadnienia

J. Mordwiłko, W sprawie ustanowienia z polskim prawie wyborczym instytucji pełnomocnika oraz możliwości głosowania drogą pocztową (głosowania korespondencyjnego), „Przegląd Sejmowy” 2001, nr 1, p. 67-71, gdzie autor przedstawia krótki przegląd stanowisk doktryny na temat treści zasady bezpośredniości wyborów i wątpliwości związanych z kwestią osobistego oddania głosu.

26 Wyrok TK z 20 lipca 2011 r., K 9/11. Trybunał odrzucił ponadto zarzut naruszenia zasady równości w aspekcie formalnym, argumentując, iż pełnomocnik oddaje głos w imieniu wyborcy, a nie w swoim. Nie dysponuje zatem dwoma głosami, ale jednym głosem własnym (jako wyborca) oraz jednym głosem realizowanym w imieniu innego wyborcy. 
partycypacji jest traktowanie głosowania przez pełnomocnika oraz głosowania korespondencyjnego jako gwarancji tej zasady, sprawiających, iż w wyborach bierze udział jak największa część tego elektoratu. Wyeliminowanie wspomnianych zagrożeń powinno powodować dalszy rozwój idei metod alternatywnego głosowania, czego dowodzi nowelizacja Kodeksu wyborczego w zakresie głosowania korespondencyjnego. Wprowadzenie tych metod oraz postępy w ich realizacji tworzą również płaszczyznę do dyskusji nad przyszłością w Polsce głosowania elektronicznego. Jednak różnego rodzaju problemy towarzyszące wyborom samorządowym z 2014 roku niewątpliwie nie stworzyły dobrego „klimatu politycznego” do dyskusji nad wprowadzeniem w Polsce $e$-votingu, jak i na kolejny progres w sferze metod głosowania alternatywnego.

Oprócz przewidzianych Kodeksem wyborczym wskazanych powyżej rozwiązań, należy także zwrócić uwagę na aspekt informacyjny. W ocenie A. Błaszczaka oraz J. Zbieranka, kampania informacyjna dotycząca nowych rozwiązań przed wyborami parlamentarnymi, które odbyły się w 2011 roku, była dość ograniczona i chyba spóźniona. ${ }^{27}$ Należy tu odnotować, że sam Kodeks wyborczy nakłada na samorządy, Państwową Komisję Wyborczą oraz obwodowe komisje wyborcze szereg obowiązków informacyjnych, w szczególności odnoszących się do osób niepełnosprawnych (patrz Rozdział 5a Kodeksu wyborczego). Oczywiście, przebicie się do świadomości wyborców z nowymi rozwiązaniami nie będzie miało efektu natychmiastowego, a upowszechnienie wiedzy w tym zakresie wymaga odpowiednich działań informacyjnych podejmowanych przez organy państwa.

Rozwiązania zawarte w Kodeksie wyborczym niewątpliwie stanowią ważny krok naprzód w kierunku pełniejszej realizacji zasady powszechności wyborów. Zarówno rozwiązania utrwalone już w polskim prawie wyborczym, jak i nowe mechanizmy alternatywnego głosowania, w opinii autora, pozwalają na zaliczenie Polski do kręgu państw, które dążą do przełamywania barier wyborczych. Zarówno rozwiązania normatywne, jak i wyrok Trybunału Konstytucyjnego świadczą o wadze, jaką przykłada się do zasady powszechności wyborów, godząc się nawet na zagrożenia, jakie niosą ze sobą alternatywne metody głosowania.

\section{BIBLIOGRAFIA}

Bannon D.P., Electoral participation and Non Voter Segmentation, (w:) W.W. Wymer Jr, J. Lees - Marshment (red.), Current Issues in Political Marketing, Binghampton 2006

Blondel J., Sinnott R., Svensson P., Representation and voter participation, European Journal of Political Research 1997, nr 32

Błaszczak A., Zbieranek J., Gwarancje korzystania z czynnego prawa wyborczego przez osoby starsze i osoby z niepełnosprawnościami, Biuletyn RPO. Źródła 2012, nr 8 
Chmaj M., Skrzydło W., System wyborczy w Rzeczypospolitej Polskiej, Warszawa 2011

Ellis A., Gratschew M., Pmmet J.H., Thiessen E., Aktywizowanie wyborców. Inicjatywy z różnych państw świata, Warszawa 2008

Krasnowolski A., Głosowanie przez pełnomocnika, głosowanie antycypowane i głosowanie korespondencyjne w krajach europejskich i Kanadzie, Warszawa 2006

Kryszeń G., Standardy prawne wolnych wyborów parlamentarnych, Białystok 2007

Mordwiłko J., W sprawie ustanowienia z polskim prawie wyborczym instytucji pełnomocnika oraz możliwości głosowania drogą pocztową (głosowania korespondencyjnego), Przegląd Sejmowy 2001, nr 1

Pintor R.L., Gratschew M. (red.), Voter Turnout Since 1945: A global Report, Stokholm 2002

Skotnicki K., Przebieg prac nad Kodeksem wyborczym, (w:) K. Skotnicki (red.) Kodeks wyborczy. Wstępna ocena, Warszawa 2011

Szabo Z., Distance voting, Raport sporządzony na potrzeby Zgromadzenia Parlamentarnego Rady Europy, Doc. nr 11434 z 12 lipca 2007, Parliamentary Assembly Working Papers, Ordinary Session 21-25 January 2008, Tom 1

Qvortrup M., First past the Postman: voting by Mail In Comparative Perspective, The Political Quarterly 2005 , Vol. 76 , No. 3

Qvortrup M., Absentee Voting in a Comparative Perspective: A Preliminary Assessment of the Experiences with Postal Voting, Submission for The Joint Standing Committee on Electoral Matters, Australian Federal Parliament, tekst dostępny w bazie academia.edu

Zbieranek J., Nowe procedury: głosowanie korespondencyjne i przez pełnomocnika, (w:) K.Skotnicki (red.) Kodeks wyborczy. Wstępna ocena, Warszawa 2011

Zbieranek J., Alternatywne procedury głosowania w Polsce na tle państw Unii Europejskiej, Biuro Analiz Sejmowych 2011, nr 3 
Głosowanie korespondencyjne oraz głosowanie przez pełnomocnika...

\section{POSTAL VOTING AND VOTING BY PROXY AS AN ALTERNATIVE VOTING METHODS IN THE LIGHT OF THE ELECTORAL CODE IN POLAND}

On 1 August 2011, the Electoral Code, a new act that comprehensively regulates electoral matters in the Republic of Poland, became effective. The article is devoted to the two new mechanisms incorporated in Polish electoral law: postal voting and voting by proxy. The author analyzes them as alternative voting methods in the light of the Electoral Code. Judgments of the Polish Constitutional Tribunal, the Code of Good Practises in Electoral Matters adopted by the Venice Commission and the doctrine of Polish constitutional law, are also taken into consideration. The article focuses on the procedural issues of postal voting and voting by proxy, as well on potential threats to the principle of personal voting and safety of the elections. In the author's opinion, the new alternative voting methods warrant considering Poland as a state that strives to overcome electoral barriers that hinder participation in public life for a large groups of voters. These provisions constitute an important step towards fuller implementation of the principle of universal suffrage and to enable citizens to truly participate in the broadest possible scope.

Keywords: voting by proxy, postal voting, elections

Słowa kluczowe: głosowanie przez pełnomocnika, głosowanie korespondencyjne, wybory 